\title{
Christianity and the Liberal Enlightenment Reforms of Criminal Law
}

\author{
Pihlajamäki, Heikki
}

Routledge

2020-05-28

Pihlajamäki , H 2020 , Christianity and the Liberal Enlightenment Reforms of Criminal Law . in M Hill QC , N Doe , RH Helmholz \& J Witte, Jr. (eds), Christianity and Criminal Law . Law and Religion, Routledge , London , pp. 80-95 . https://doi.org/10.4324/9781003015260-7

http://hdl.handle.net/10138/336795

https://doi.org/10.4324/9781003015260-7

unspecified

acceptedVersion

Downloaded from Helda, University of Helsinki institutional repository.

This is an electronic reprint of the original article.

This reprint may differ from the original in pagination and typographic detail.

Please cite the original version. 


\title{
Christianity and the Liberal Enlightenment Reforms of Criminal Law
}

\author{
Heikki Pihlajamäki, University of Helsinki
}

\section{Introduction}

According to the traditional view, the Enlightenment brought with it a secularization of philosophical and social thinking. Contributing significantly to the process of modernization in the West, secularization was a fundamental feature of the Enlightenment. Separation of church and state and theoretical formulations of religious tolerance limited state control over religious compliance. Philosophical skepticism, atheism, and influential critiques of the church and clergy as institutions emerged. ${ }^{1}$

This view of the Enlightenment dominates the histories of Western criminal justice, in both common law and civil law. Whereas ancien régime criminal justice essentially depended on a Christian world-view, first natural law theorists and then Enlightenment reformers, so the argument goes, delivered a decisive blow to Christianity as law's organizing principle. ${ }^{2}$ Particularly in criminal law, late eighteenth- and early nineteenth-century Enlightenment caused an upheaval that brought humankind from pre-modernity to the modern era. This was the epoch of reforms that transformed European criminal justice, which had taken its shape in the Middle Ages, to something more closely resembling the system we have today. Eberhard Schmidt connected the new criminal justice to "secularization, rationalization, humanization and liberalization." ${ }^{3}$ As another prominent German legal historian described it, "punishment no longer meant, as in the medieval theocratic system, God's revenge, but develops, following secular natural law, as a reaction to an earlier breach of the norm." "4 Punishments now needed to match crimes; not, however, according to the

\footnotetext{
${ }^{1}$ One of the most influential modern works developing these themes is Gay, Peter: The Enlightenment 1-2 (Knopf, New York, 1966, 1969). See also, e.g., Dupré, Louis: Religion and the Rise of Modern Culture (University of Notre Dame Press, Notre Dame, Ind., 2008); Jacob, Margaret C.: The Radical Enlightenment: Pantheists, Freemasons, and Republicans (Allen \& Unwin, London, 1981).

${ }^{2}$ See Schmidt, Eberhardt: Einführung in die Geschichte der deutschen Strafrechtspflege (Vandenhoeck \& Ruprecht, Göttingen, 1983, orig. 1947).

${ }^{3}$ Schmidt, Eberhard: 'Die geistesgeschichtliche Bedeutung der Aufklärung für die Entwicklung der Strafjustiz aus der Sicht des 20. Jahrhunderts', Revue Pénale Suisse 75 (1958): 341-360, 343.

4 "Strafe bedeutet nicht mehr wie im theokratischen System des Mittelalters, Gott zu rächen, sondern erschöpft sich für das profane Naturrecht in der Reaktion auf einen vorangegangenen Normverstoß.” Translation: HP. In: Rüping, Hinrich: Grundri $\beta$ der Strafrechtsgeschichte, 59 (Beck, Munich), 1991).
} 
mirroring logic of talion, but rather corresponding to the harm the crime had caused the victim and society. This led, finally, to the abolition of torture and, if not abolition of the death penalty everywhere, at least to a considerable decrease in its use. Most breaches of Christian doctrine were no longer crimes at all, and crimes defined as such by Christian doctrine but which were not harmful to society (such as suicide) were decriminalized. Christian morality and the law parted ways, which led to lighter punishments for crimes such as blasphemy and sodomy, now punished only insofar as they threatened the public order. All punishments were now to be applied rationally, according to many Enlightenment theorists, so that they would further salus publica, the common good, according to the principles of utilitarianism (Böhmer, Bentham). Rationalism and secularism also led to constructs such as P. J. A. Feuerbach's theory of "psychological compulsion."

Reformers considered ancien régime criminal justice cruel and arbitrary. This, combined with the religious notion of crime as conceptually connected to sin, as well as the haphazard nature of the inquisitorial procedure coupled with judicial torture made the old system intolerable for the reformers. The disproportionality and arbitrariness of the punishments did not improve matters. Consequently, the critique and demands for reform were directed at three different areas: the secularization of criminal law by giving the state, with its utilitarian approach to punishment, the sole right to punish, the establishment of crimes and punishments through legislation only and the application of the proportionality principle between crime and punishment. General leniency in sentencing could be added to these. ${ }^{5}$

For some decades now, the traditional narrative of the Enlightenment as a secularization procedure has become more nuanced, with the overarching theme being "restoring religion to the Enlightenment." 6 The scholarly consensus has significantly changed: scholars now generally agree that religion continued to play a decisive role in people's lives, as well as in politics and culture even during (and after) the Enlightenment. ${ }^{7}$ The authority of the Bible all but waned, as its teaching changed to secure the Bible's position as a fundament of Western culture. ${ }^{8}$ Enlightened theologians

\footnotetext{
${ }^{5}$ Hernández Marcos, Maximiliano: 'Conceptual Aspects of Legal Enlightenment in Europe', in Canale, Damiano, Grossi, Paolo, and Hoffmann, Hasso (eds.): A Treatise of Legal Philosophy and General Jurisprudence, Vol. 9: A History of the Philosophy of Law in the Civil Law World, 69-143, 125-126 (Springer, Dordrecht, 2009).

${ }^{6}$ See, for instance, van Kley, Dale K.: The Religious Origins of the French Revolution: From Calvin to the Civil Constitution, 1560-1791 (Yale University Press, New Haven, Conn., 1975); Grote, Simon: 'Review-Essay: Religion and Enlightenment', Journal of the History of Ideas 75:1 (2014): 137-161; Coleman, Charly: 'Resacralizing the World: The Fate of Secularization in Enlightenment Historiography', The Journal of Modern History 82 (2010): 368-395.

${ }^{7}$ Haakonssen, Knut: 'Enlightened Dissent: An Introduction', in Haakonssen, Knut (ed.): Religion and Enlightenment: Rational Dissent in Eighteenth-Century Britain, 2-3 (Cambridge University Press, Cambridge, 1996); Clark, J. C. D.: English Society, 1688-1832: Religion, Ideology and Politics during the Ancien Régime (Cambridge University Press, Cambridge, 2000).

${ }^{8}$ Sheehan, Jonathan: The Enlightenment Bible: Translation, Scholarship, Bible (Princeton University Press, Princeton, 2005).
} 
refashioned Christian teachings to suit modern natural science and promoted religious tolerance. Although skeptical towards religion, and oriented toward solving social and scientific problems with the help of rationality, few philosophes were actually atheists. Voltaire, one of the biggest critics of the church and Christianity, even said, "whatever the present-day scholars may say, one can be a very good philosopher and still believe in God. Atheists have never responded to the objection that a clock proves the existence of a clockmaker."9

This article provides a brief overview of the reformers' starting point, the criminal justice system of the ancien régime (Part II). I will then move on to a discussion of enlightened criminal law thinkers and religion, and I will ask how religion featured in their writings and how it affected their theories (Part III). Part IV will conclude and summarize the findings of the article.

\section{The Criminal Justice System of the Ancien Régime}

The criminal justice system, which the Enlightenment philosophers criticized, was firmly rooted in medieval canon law. Inquisitorial procedure emerged in the late eleventh century and became a general mode of procedure in canon law during the thirteenth century. In the late Middle Ages and the beginning of the early modern period, inquisitorial procedure spread to secular procedure and became the standard way of managing crime in most regions of Europe. Inquisitorial procedure in fact created criminal law in the modern sense, as separate from civil procedure. Since the Middle Ages, criminal procedure was divided into inquisitorial, adversarial and (sometimes) denunciatory procedures. ${ }^{10}$

The rise of the inquisitorial procedure brought with it tough penalties. When public powers - the church, princes and cities - took over punishing, they used not only fines but also, increasingly, capital and corporal punishments. Part and parcel of this was the change in the law of evidence. Before the transformation of the thirteenth century, legal procedures relied on compurgators, oaths

\footnotetext{
${ }^{9}$ Voltaire to Jean-François Dufour, seigneur du Villevieille, August 26, 1768, in Voltaire: Selected Letters of Voltaire, 276 (New York University Press, New York, 1973); Love, Ronald S.: The Enlightenment, 57 (Greenwood Press, Westport, Conn., year?); Barnett, S. J.: The Enlightenment and Religion: the Myths of Modernity (Manchester University Press, Manchester, 2003).

${ }^{10}$ Pihlajamäki, Heikki and Korpiola, Mia: 'Medieval Canon Law: The Origins of Modern Criminal Law', in Dubber, Markus D. and Hörnle, Tatjana (eds.): The Oxford Handbook of Criminal Law, 201-224 (Oxford University Press, Oxford, 2014).
} 
and ordeals. After the Fourth Lateran Council (1215), clerics could no longer participate in ordeals, and since the primary responsibility of their administration had been with the church, the practice became extinct within a few decades. ${ }^{11}$

Ordeals were replaced by a statutory theory of proof, a theory developed by legal scholars. According to the theory, in serious criminal cases "full proof" was needed for condemnation. Such proof consisted of confession or two trustworthy eyewitnesses. An integral part of the theory was judicial torture, which helped to extract confessions in cases where some evidence existed but was insufficient.

Early modern criminal law scholars continued building on these medieval structures. The control of serious crime continued to be based on capital and corporal punishments. "Spectacles of suffering," as Pieter Spierenburg has called early modern executions, dominated the visual image of crime control, ${ }^{12}$ even though in practice the number of capital punishment sentences put into effect had been decreasing in most Western countries since the seventeenth century. ${ }^{13}$ Until its abolition, first by "Enlightened monarchs" such as Fredrik the Great of Prussia, Catherine the Great of Russia and Charles III of Sweden, judicial torture continued to be formally in force as well. However, as John Langbein has demonstrated, the use of judicial torture and capital punishment diminished as of the beginning of the early modern period. The reason for their decline was the emergence of an alternative, the "extraordinary punishment." It too had formed part of medieval criminal law theory. The judge was to resort to "ordinary punishment" (poena ordinaria; typically, capital punishment) if no alleviating or aggravating circumstances were present. Such circumstances would lead to an "extraordinary punishment," (poena extraordinaria) which could be, depending on the nature of the circumstances, either more lenient or more severe than the ordinary punishment. In practice, the extraordinary punishments most often served to alleviate harsh capital punishments. Extraordinary punishments also helped in cases in which full proof was lacking but the evidence was otherwise convincing. ${ }^{14}$

The rise of the modern state and its organized way of treating crime and convicted criminals favoured an extended use of extraordinary punishment. Viable alternatives for the death penalty emerged. Galley service and forced labour were typical examples of punishments whose

\footnotetext{
${ }^{11}$ Bartlett, Robert: Trial by Fire and Water: The Medieval Judicial Ordeal (Clarendon Press, Oxford, 1986).

${ }^{12}$ Spierenburg, Pieter: Spectacles of Suffering: Executions and the Evolution of Repression: From a Preindustrial Metropolis to the European Experience (Cambridge: Cambridge University Press, 1984).

${ }^{13}$ Evans, Richard: Rituals of Retribution: Capital Punishment in Germany, 1500-1987, 42 (Penguin Books, Harmondsworth, 1996).

${ }^{14}$ On the early modern criminal justice system, see Meccarelli, Massimo in Pihlajamäki, Heikki et al.: The Oxford Handbook of European Legal History, 632-654 (Oxford University Press, Oxford, 2018).
} 
organization demanded state machinery unavailable to medieval polities but already within the reach of modern states. As a result, the use of the death penalty declined and, by extension, judicial torture became increasingly unnecessary. This evidently much more gradual erosion of judicial torture led Langbein to call the narrative of Enlightenment reformers abolishing torture a "fairy tale": the decisive turn toward the demise of torture had occurred long before the Enlightenment. ${ }^{15}$

Nevertheless, at the end of the eighteenth century the medieval core of Western criminal justice remained intact. Even though capital punishment and judicial torture were less frequent than they once had been, these gruesome institutions were still available and used. The case of the cruel execution of Damiens, the regicide, which Foucault describes in Discipline and Punish ${ }^{16}$ may have been exceptional, but in eighteenth-century Europe it was still possible that the death penalty could follow from even a minor crime, such as stealing a handkerchief. ${ }^{17}$ From the point of view of the reformers, the fact that capital punishment and torture were used less than a couple of hundred years earlier (if the reformers were even aware of this) was probably just as irrelevant as it is for opponents of the death penalty in the United States or China today.

In theory, one of the main areas in which the death penalty and judicial torture appeared were religious crimes and those connected to the Christian faith: blasphemy, witchcraft, sodomy and adultery. However, although the letter of the law remained unchanged, in the legal practice of many European regions these crimes no longer carried capital punishment. As for the organization of the judicial system, the church's influence had begun to wane as well. In Protestant regions, the state had taken over the courts of the Catholic forum externum as early as the sixteenth century, although Protestant churches remained closely connected to the state and exercised social control jointly with it. ${ }^{18}$ Similarly, in Catholic areas of the West the church courts had lost much of their jurisdiction to secular courts long before the Enlightenment era. ${ }^{19}$

Despite these changes, the Christian faith still provided the main legitimation for the criminal system. Although general deterrence and betterment of the criminal already figured in the punishment theories of thinkers such as Antonius Matthaeus II (1601-1654) ${ }^{20}$, retaliation or

\footnotetext{
${ }^{15}$ Langbein, John: Torture and the Law of Proof: Europe and England in the Ancien Régime (The University of Chicago Press, Chicago, 1976).

${ }^{16}$ Foucault, Michel: Discipline and Punish: The Birth of the Prison (Random House, New York, 1975).

${ }^{17}$ See Hostettler, John: Cesare Beccaria: The Genius of 'On Crimes and Punishments' (Waterside Press, Hook, 2011).

${ }^{18}$ Pihlajamäki, Heikki: Executor divinarum et suarum legum: Criminal Law and the Lutheran Reformation, 171-204 (Brill, Leiden, 2006).

${ }^{19}$ Prodi, Paolo: Eine Geschichte der Gerechtigkeit: Vom Recht Gottes zum modernen Rechtsstaat (Beck, [München Munich?], 2003).

${ }^{20}$ Jan-Willem Oosterhuis (presentation at the Annual Meeting of American Society for Legal History, 11 November,2018).
} 
retribution remained an important justification for punishments. Crime merited punishment because crime constituted a sin, which was harmful to society. If crimes went unpunished, not only did the individual criminal in question, but also the ruler and his realm, risk perdition. A good example of Lutheran thinking is Benedict Carpzov, whose thinking influenced many generations of European criminal law theorists. ${ }^{21}$

III. The Reforms, Reformers and Religion

The concept of "Enlightenment" is notoriously challenging. Some scholars define it as the period typically ranging from the mid-eighteenth to the early nineteenth century, whereas others prefer to define it as ways of thinking which originated in roughly that period. For the purposes of this article, it should be sufficient to assume a pragmatic approach and proceed from a conventional list of Enlightenment thinkers. My purpose is to look at their views on religion and to see how those views affected their teachings on criminal law. I will start with Christian Thomasius.

Christian Thomasius (1655-1728), the first representative of German Enlightenment and a major reformer of criminal law, is considered an important secularizer of criminal law and is mainly known for his campaigns against inquisitorial procedure, judicial torture and for the decriminalization of bigamy, witchcraft and heresy. However, as Thomas Ahnert has shown, none of Thomasius's key teachings can be understood without reference to his religious beliefs. True, his contemporaries considered them outrageous but none would have described him as anti-religious. ${ }^{22}$ As Ian Hunter demonstrates, Thomasius effectively mobilized the Lutheran concept of Christians' inner freedom not only to shield Christian faith from interference by the state, but also to protect religion from the secular systems of power - such as criminal justice. ${ }^{23}$ Interestingly, later representatives of criminal law - such as Beccaria, Pagano, and Feuerbach - adopted similar views as regards the relationship between religion and the state.

\footnotetext{
${ }^{21}$ Rüping, Hinrich: Grundriss der Strafrechtsgeschichte, 43 (Beck, [München (Munich?], 1991).

${ }^{22}$ Ahnert, Thomas: Religion and the Origins of the German Enlightenment: Faith and the Reform of Learning in the Thought of Christian Thomasius (University of Rochester Press, Rochester, NY, 2006).

${ }^{23}$ See Hunter, Ian: The Secularisation of the Confessional State: the Political Thought of Christian Thomasius (Cambridge University Press, Cambridge, 2007).
} 
Similarly, although Charles de Montesquieu (1689-1755) was critical of the Catholic Church and the clergy as institutions, he was not against religion as such. Montesquieu discusses religion in Books 24 to 26 of De l'esprit des lois (1748). For him, religion could be useful in strengthening morality, but it could also undermine it (XXIV, 21). Religion needed not contradict secular ends, and Christians could also be good citizens (XXIV, 6). According to Montesquieu, "[r]eligion may [even] support a state, when the laws themselves are incapable of doing it." (XXIV, 16).

Montesquieu suggests that both religion and civil law are responsible for the forming of "good citizens." When one them fails in the task, the other one should step in (XXIV, 14). ${ }^{24}$

For many historians, Cesare Beccaria marked the decisive change from pre-modern to modern criminal law. His major work, the little book called On Crimes and Punishments (1764), was the big bang of criminal law reforms all over the Western hemisphere. This was not so much because of its originality: none of Beccaria's ideas were novel, but he succeeded in presenting them in an accessible form. ${ }^{25}$ Translated into many languages, On Crimes and Punishments spread quickly around Europe and the Americas. On Crimes and Punishments became (and still is) mostly known for its utilitarian and rationalist tone. For Beccaria, punishments were necessary and rational only insofar as they deterred people from committing crimes (general deterrence). Therefore, it is rational that punishments be proportionate to the crime. The famous legality principle - no crime without law, no punishment without law (nullum crimen sine lege, nulla poena sine lege) - flowed from the same idea of general deterrence: people should be able to know beforehand what deeds were criminal and which punishment would follow which crime. Furthermore, Beccaria was opposed to the death penalty and judicial torture.

It is also difficult to deny the general view according to which religion plays little role in Beccaria's work, although On Crimes and Punishments does not remain silent on the theme. Beccaria writes:

"But our religion is more holy than that of the Romans, and consequently impiety is a greater crime. Granted. God will punish it. The part of man is, to punish that which is criminal in the public disorder which the impiety hath occasioned. But if in the act of impiety the delinquent hath not even stolen a handkerchief; if the ceremonies of

\footnotetext{
${ }^{24}$ Kingston, Rebecca: 'Montesquieu on Religion and on the Question of Toleration', in David W. Carrithers et al (eds.): Montesquieu's Science of Politics: Essays on 'The Spirit of Laws', 375-408 (Rowman and Littlefield, Oxford, 2001).

${ }^{25}$ For instance, many philosophers and jurists opposed judicial torture at least from the sixteenth century onwards, see Schmoeckel, Mathias: Humantität und Staatsräson: Die Abschaffung der Folter in Europa und die Entwicklung des gemainen Straf- und Beweisrechts seit dem hohen Mittelalter, 93-186 (Böhlau, [Köln Cologne?], 2000); also in legal practice, judicial torture had been on the decline long before the Enlightenment reformers' criticism. As for the legal practice in Toulouse, see Silverman, Lisa: Tortured Subjects: Pain, Truth, and the Body in Early Modern France, 71-84 (The University of Chicago Press, Chicago, 2001).
} 
religion have been in no wise disturbed, shall we, as I said before, punish the impiety as we would punish parricide?" (Chapter VI)

Beccaria does not forcefully deny the importance of religion, it just does not have a place in his system. It is up to man to take care of discipline - God will punish crimes against religion:

"Religion is of God to man; the civil law is of you to your people." (Ch. IV: On the Extirpation of Heresy).

Neither does a human judge have access to the mysteries of sin. Therefore, comparing crime to sin is beyond human capacity and man should not engage himself in such activity:

"In short, others have imagined, that the greatness of the sin should aggravate the crime. But the fallacy of this opinion will appear on the slightest consideration of the relations between man and man, and between God and man. The relations between man and man are relations of equality. Necessity alone hath produced, from the opposition of private passions and interests, the idea of public utility, which is the foundation of human justice. The other are relations of dependence, between an imperfect creature and his Creator, the most perfect of beings, who has reserved to himself the sole right of being both lawgiver and judge; for he alone can, without injustice, be, at the same time, both one and the other. If he hath decreed eternal punishments for those who disobey his will, shall an insect dare to put himself in the place of divine justice, to pretend to punish for the Almighty, who is himself allsufficient; who cannot receive impressions of pleasure or pain, and who alone, of all other beings, acts without being acted upon? The degree of sin depends on the malignity of the heart, which is impenetrable to finite being. How then can the degree of sin serve as a standard to determine the degree of crimes? If that wereadmitted, men may punish when God pardons, and pardon when God condemns; and thus act in opposition to the Supreme Being. (Chapter VII: On Estimating the Degree of Crimes)

Beccaria also comments on the relationship between canon law and secular law when he discusses judicial torture and confession. According to Beccaria, the sacrament of confession has been misused on several occasions, when penitents sought absolution in advance, before committing a serious crime. For instance, "Jaurigny and Balthazar Gerard, who assassinated William I. Prince of Orange; Clement the Dominican, Chatel, Ravaillac, and all the other parricides of those times, went to confession before they committed their crimes." (Chapter XVI). Therefore, "[c]onfession, which was intended as a curb to iniquity, hath frequently, in times of confusion and seduction, become an 
incentive to wickedness," and, "[p]robably it was for this reason, that so many Christian states have abolished a holy institution, which appeared to be as dangerous as useful."

Beccaria speculates in the chapter on torture that it is probably a human application of purgatory:

"Now infamy is a stain, and if the punishments and fire of purgatory can take away all spiritual stains, why should not the pain of torture take away those of a civil nature?" If torture was akin to purgatory, then confession of a crime was related to a confession of sin: "I imagine that the confession of a criminal, which in some tribunals is required, as being essential to his condemnation, has a similar origin, and has been taken from the mysterious tribunal of penitence, where the confession of sins is a necessary part of the sacrament. Thus have men abused the unerring light of revelation; and in the times of tractable ignorance, having no other, they naturally had recourse to it on every occasion, making the most remote and absurd applications."

Beccaria was thus not squarely against the Christian faith, but rather removed it from the secular system. The secular system was for human beings to operate. This was not, however, the view of all who supported Beccaria's reformist views and developed them further. I will take two examples of such scholars, both of the Italian school: Gaetano Filangieri and Francesco Mario Pagano.

Besides Beccaria, Gaetano Filangieri is certainly the best known internationally of the early Italian criminal law scholars. His main work, The Science of Legislation (La Scienza della legislazione) appeared in 1780-1791 in five volumes, of which the third was devoted to criminal law and procedure. His critical points largely followed those of Beccaria. According to Filangieri, judicial torture was not only inhumanely cruel but also produced uncertain results (III, 147-148). He advocated for the limitation of the death penalty, but accepted it in certain serious cases. His reform philosophy thus followed Beccaria's.

However, and unlike Beccaria, Filangieri discussed religion at length. Like many of his contemporary intellectuals, Filangieri was a Freemason and a deist. He did not consider religion necessarily a superstitious fraud, but thought that religion could play an important role in the construction and maintenance of the social order. Religion was "so inherent to the nature of man, so necessary to the formation, perfection and preservation of society, and so terrible in its degeneration." Religion belonged, however, to the "internal forum," whereas politics was a matter of the outer forum. Freemasons' lodges, for Filangieri, could be an excellent tool in developing Christianity into a civil religion which would be spread to the masses and which could help combat the traditional power of the church and the privileges of the clergy. Civil religion, the way Filangieri 
envisaged it, had nothing to do with the church as a separate power competing with the secular power, and nothing to do with what Filangieri and other deists considered superstitious beliefs. Filangieri's vision of a civil religion was, however, in complete disagreement with the Jacobin idea of uprooting the existing religions altogether and founding a completely new one. ${ }^{26}$

Filangieri thus thought that religious sentiments were unavoidable for humans and, in fact, religion could be used as a social glue. His reference to the canon law institutions of internal and external fora, which had their origins in the medieval period is revealing: since the canon omniusque sexus had been issued in 1215, the two fora had formed the branches of ecclesiastical social control. In Filangieri's thinking, an external forum of the church had of course no place. Instead, the external forum was wholly reserved for the secular power, which did not have to compete with the church.

Francesco Mario Pagano (1748-99) was a contemporary of Filangieri and a well-known international figure, despite the fact that standard lists of Enlightenment criminal justice reformers now seldom include his name. Pagano studied law at Naples, and later became professor of moral philosophy and jurisprudence. Pagano's Saggi politici (Political Essays, 1783-5) is a philosophical history of the Kingdom of Naples. Like Beccaria and Filangieri's works, the Saggi argues for more lenient criminal justice, and against torture and capital punishment. ${ }^{27}$ Pagano authored a republican constitution for Naples, and was executed when the short-lived republic fell in $1799 .{ }^{28}$

\section{From the point of view of this article, Pagano's Considerations on Criminal Procedure}

(Considerazioni Sul Processo Criminale) (1787) is pivotal. Unlike Beccaria, Pagano departed from the principle of talion. Not, however, in the draconic sense of the term - eye for an eye - but rather meaning that every violation of a right had to paid back by a loss of a right. ${ }^{29} 30$

Pagano's attitude towards religion was much closer to Beccaria's than Filangieri's. He was critical of the church and blamed past canon lawyers for the degeneration of the inquisitorial procedure inherited, as he saw it, from the ancient Romans - into a secretive and arbitrary business. The inquisitorial procedure, such as the Roman emperors had introduced it, had been a transparent process, but decretals of the medieval popes such as Innocent III (de accusationibus, de judiciis)

\footnotetext{
${ }^{26}$ Viroli, Maurizio: Machiavelli's God, 249-251 (Princeton University Press, Princeton, 2010). Filangieri, Gaetano: Scienza della legislation I, 57-58 (quoted from Maurizio Viroli: Machiavelli’s God, 250.)

${ }^{27}$ Pagano, Francesco Mario: Considerazioni Sul Processo Criminale, 150-153, 184.

${ }^{28}$ The Cambridge History of Eighteenth-Century Political Thought, 765 (Cambridge University Press, Cambridge, 2008).

${ }^{29}$ Shahibzadeh, Omid: Penal Philosophy in 18th Century Italy: A Historical Enquiry into the Ideas of Francesco Mario Pagano, 3 (unpublished master's thesis, University of Oslo, 2016).

${ }^{30}$ Pagano, Francesco Mario: Considerazioni Sul Processo Criminale, 33: 'L'arbitrario procedimento senza formalità e senza processo è l'indice, e l'istrumento insime di un un fateale illimitato dispotismo.'
} 
had transformed it. Emperor Frederick the Great of Prussia had adopted the inquisitorial mode of procedure in his constitution Inquisitiones generales, "but not with its ancient methods, but rather with that terrible and ferocious one introduced by the churchmen." That had been "one step too far" (“un passo di più") from the ecclesiastics. ${ }^{31} 32$

Pagano wrote little about the church, but his main idea was clear. The Catholic Church was, historically and in Pagano's time, connected to the feudal structures that supported the early modern state. This position needed to be eradicated to make way for a liberal state. This basic position formulated in Saggi is reformulated in Considerazioni when Pagano discusses the institution of the oath. Religious oaths needed to be abolished from legal proceedings. For Pagano, an oath was "moral violence" (violenza morale) just as judicial torture was physical violence (violenza fisica). An oath did not constitute moral violence because of its connection to sin, but because it violated the human dignity of the one giving the oath. The institution of the oath represented, as de Angelis puts it, a compromise between church and state, a concession that had been made to fit ecclesiastical and religious interests into a procedure, which now needed to be essentially secular. In Pagano's time, better truth-finding mechanisms than the oath already existed as forensic techniques had begun to advance. ${ }^{33}$

Similarly, as regards the theory of evidence, the elevated position of confession (regina probationum since the Middle Ages) needed to the changed. Confession had to be relegated to the same level with all other instruments of evidence: 'La confessione dev'essere sostenuta dalla prova del delitto." Obviously, Pagano's thinking ran along the same lines as the general European reform ideas of the late eighteenth and early nineteenth centuries, which emphasized the importance of ridding the system of proofs of the remaining vestiges of the Roman canon theory of proof. Since the thirteenth and fourteenth centuries, the concept of full proof had played a major role. It consisted of what Pagano called "natural proofs" ("prova naturale"), confession and eyewitnesses, as against other, "indirect" proofs. A prominent position given to natural proofs was, according to Pagano, a mark of an underdeveloped, barbaric legal order: “[...] le barbare nazioni amano una pronta giustizia, ed alle loro semplici idee conforme; attendono solo alla realità del fatto, ed alla naturale pruova" (Considerazioni, VI).

\footnotetext{
${ }^{31}$ Pagano, Considearzione, 70-71. Shahibzadeh, 88.

32 de Angelis, Paulo: Politica e giurisdizione nel pensiero di Francisco Mario Pagano (Publisher?, Naples, 2006).

${ }^{33}$ De Angelis, 70-71. Beccaria had touched on the subject of the oath as well, stating that it was becoming a mere formality. § XI Dei delittie delle pene ("Il giuramento a poco a poco diviene una semplice formalità, distruggendosi in questa maniera la forza dei sentimentidi Religione, unico pegno dell'onestà della maggior parte degli Uomini”).
} 
The secular nature of the Enlightenment reforms lay in the fact that the right to punish (ius puniendi) now became the sole prerogative of the state. Crime was no longer derived from sin; instead, crime was defined through the social harm it produced. Crimes pertaining to conscience or private morals were contrary to earlier thinking, not, in fact, crimes at all. This is what Beccaria, Filangieri, and Pagano - and the great majority of nineteenth-century criminal law thinkers - had in common.

Not all of them, however, held this view. Interestingly, William Blackstone, although greatly influenced by Beccaria, ${ }^{34}$ still retained God in his theory of punishment: "To shed the blood of our fellow creature is a matter that requires the greatest deliberation, and the fullest conviction of our own authority: for life is the immediate gift of God to man; which neither he can resign, nor can it be taken from him, unless by the command or permission of him who gave it; either expressly revealed, or collected from the laws of nature or society by clear and indisputable demonstration". On the other hand, "punishments are ... only inflicted for abuse of that free will, which God has given to man." 35

In one area of criminal justice, the execution of punishments, the effects of secularization remained particularly modest. One of the effects of modernization of criminal law was that it brought with it a thorough change of the system of punishment. When punishments were to be meted out according to the principle of proportionality, capital and corporal punishments could no longer serve as part of the backbone of the punishment system. Fines did not serve this purpose very well either, because most convicted criminals did not have the means to pay. Imprisonment, however, had its benefits. It became, as Michael Ignatieff put it, "a just measure of pain" 36 : long sentences for serious crimes, shorter sentences for less serious crimes. Imprisonment was also flexible in the sense that it could be made to meet several other objectives. During their prison term, inmates could be resocialized to help them return to society as useful citizens.

Prison reform was thus an integral part of the transformation of criminal justice around the turn of the eighteenth and nineteenth centuries. John Howard's famous account of British prisons in the 1770 s gives a vivid account of the problems that needed to be addressed. The old prisons were

\footnotetext{
${ }^{34}$ Harcourt, Bernard E.: 'Beccaria's "On Crimes and Punishments": A Mirror on the History of the Foundations of Modern Criminal Law’, Buffalo Criminal Law Review Vol. 6, No. 2 (January 2003), 691-83.

${ }^{35}$ Blackstone, William: Commentaries on the Laws of England (1765-1769), Book 4, Chapter 1 Of the Nature of Crimes; and Their Punishment.

${ }^{36}$ Ignatieff, Michael: A Just Measure of Pain: The Penitentiary in the Industrial Revolution 1750-1850 (Pantheon Books, New York, 1978).
} 
overcrowded and difficult to supervise. Diseases and violence spread easily, and hardened criminals were housed together with first-timers. ${ }^{37}$ Prison doctors and infirmaries were on the list of demands of the reformers, many of whom were devout Christians, such as Quakers and Evangelicals. To combat disease, prisons were to be dry, heated, clean and hygienic. ${ }^{38}$ Even Jeremy Bentham, a wellknown opponent of religions, envisaged a chapel as a necessary part of his Panopticon. In an early draft for a frontispiece of a planned book on the Panopticon, Bentham had sketched the words from the 139th Psalm: "Thou art about my path, and about my bed: and spiest out all my ways." Chapels were then built in prisons following (albeit otherwise loosely) the Panopticon model, such as the Pentonville prison in London. ${ }^{39}$

The Auburn model - daytime labour, nighttime solitude - dominated early nineteenth-century American disciplinary institutions. Protestant reformers also made religion an integral part of everyday life in prisons. It was hoped - as many, contrary to criminological studies, still do - that prison could and should do something to reform criminals. In American prisons, as Jennifer Graber has shown, the prison chaplain became one of the key administrative figures. Chaplains continuously reminded inmates of suffering and redemption, and religious ideology was an important part of prison discipline and continued to be so even after the Civil War. ${ }^{40}$ The same was true for France after 1816, when all prisoners were obliged to attend services every Sunday and on religious holidays. In 1868, French prisons counted approximately 800 priests among their staff. Inmates were placed in disciplinary institutions according to their faith, so that those representing "dissident faiths" - Protestants and Jews - served mainly in Ensisheim, Nîmes, and Haguenau. ${ }^{41}$

One more point deserves a mention. A few features of modern criminal law, which, during the nineteenth century became the rule rather than the exception, had their roots in the Middle Ages. Paradoxically, the "secularizing" Enlightenment reforms, rather than rooting them out, reinforced them. Imprisonment, as Michel Foucault informs us in Discipline and Punish, ${ }^{42}$ was not a modern

\footnotetext{
${ }^{37}$ Howard, John: The State of the Prisons in England and Wales, with Preliminary Observations, and an Account of Some Foreign Prisons (Warrington, 1777).

${ }^{38}$ Steadman, Philip: 'The Contradictions of Jeremy Bentham's Panopticon Penitentiary', The Journal of Bentham Studies 9 (2007), 1-31, 5; Evans, Robin: The Fabrication of Virtue: English Prison Architecture, 1750-1840, 354-357 (Cambridge: Cambridge University Press, 1982).

${ }^{39}$ Steadman, 7, 9.

${ }^{40}$ Graber, Jennifer: The Furnace of Affliction: Prisons and Religion in Antebellum America (University of North Carolina Press, Chapel Hill, VA, 2011).

${ }^{41}$ Petit, Jacques-Guy et al.: Histoire des prisons en France (1789-2000,) 86-87 (Editions Privat, Toulouse, 2002).

${ }^{42}$ See Spierenburg, Pieter: The Spectacle of Suffering: Executions and the Evolution of Repression: From a Preindustrial metropolis to the European Experience, viii-ix (Cambridge University Press, Cambridge, 1984).
} 
innovation but, instead, had been part of the Catholic Church's tradition since the early Middle Ages. Solitary confinement was part of penitential practice, and, especially since the 1215 Fourth Lateran Council had prohibited churchmen from shedding blood, the penitentiary's use as an ecclesiastical punishment widened. In the early modern period, different forms of penitentiary were taken into use in England and the Netherlands. In the nineteenth century, imprisonment became the major punishment for serious crime in modern criminal justice systems. ${ }^{43}$

Another central component of modern criminal justice systems is the notion of individual culpability. The significance of individual culpability emerged as a product of twelfth- and thirteenth-century canon law at its most innovative. Canonists such as Raymundus de Penyafort developed and refined the jurisprudence of penance, stressing the individual nature of sin. The assessment of the sin's harmfulness belonged to the jurisdiction of the priest (forum internum). The penitential literature and practice were pivotally influential to secular criminal law as well. Although sin and crime were not the same, the two concepts were closely related. Not all sins were crimes, but all crimes were sins. According to a common understanding, all sins that found an expression in observable deeds and were serious enough to "scandalize" society were also crimes. The decretists of the late twelfth century developed teachings on necessity, duress, and self-defence, which were then, in the nineteenth century, systematically worked into the "general part" (allgemeine Lehren) of modern continental criminal law. ${ }^{44}$

Even though some Enlightenment reformers were eager to rid criminal justice of its Christian underpinnings, it was impossible to do so without demolishing the whole system. In fact, the two central medieval inventions which survived the early modern period, incarceration and individualized punishment, were useful enough to be included as fundamental parts of the transformed criminal justice system of the modern era.

\footnotetext{
${ }^{43}$ Sellin, Thorsten: Pioneering in Penology: The Amsterdam Houses of Correction in the Sixteenth and Seventeenth Centuries (The University of Pennsylvania Press, Philadelphia, 1944); Whitman, James Q.: 'The Transition to Modernity', in Dubber, Markus D. and Hörnle, Tatjana (eds.): The Oxford Handbook of Criminal Law, 84-110 (Oxford University Press, Oxford, 2013); on medieval Italian prisons, see Geltner, Guy: The Medieval Prison: A Social History (Princeton University Press, Princeton and Oxford, 2008).

${ }^{44}$ See Kuttner, Stepjhan: Kanonistische Schuldlehre von Gratian bis auf die Dekretalen Gregors IX systematisch auf Grund der handschriftlichen Quellen dargestellt (Biblioteca Apostolica Vaticana, Città del Vaticano, 1935); Engelmann, Woldemar: Die Schuldlehre der Postglossatoren und ihre Fortentwicklung: eine historisch-dogmatische Darstellung der kriminellen Schuldlehre der italianischen Juristen des Mittelalters seit Accursius (1895, new edition Scientia Verlag, Aalen, 1965).
} 


\section{Conclusions}

The traditional view of the Enlightenment as a secularization process has greatly changed during the last few decades. Most experts now agree that religion survived the Enlightenment better than previously assumed. It would be difficult to make a similarly bold statement as regards criminal law to claim that, after the major Enlightenment critique of the late eighteenth and early nineteenth centuries, Christianity remained an important part of criminal law. This was simply not the case. In many ways, the tide did indeed turn. Modern criminal law emerged, and its relationship with Christianity changed in important ways. The attacks on Christianity and the clergy as institutions removed many institutional barriers that had emanated from rigid Christian ideology. The decriminalization of witchcraft is perhaps not the best of examples, because by the time the Enlightenment critique against witchcraft trials started, they were mostly over. After the late eighteenth-century radical scholars delivered their input, Christianity no longer served as the background ideology, "punishment theory," of criminal law. Few criminal law theorists believed any more that criminal law was necessary to channel God's retribution on sinners. Instead, most thought that criminal law, at its best, could affect potential wrongdoers through either general deterrence (Beccaria) or individual psychology (Feuerbach). As concerns the elements of crime, religious arguments no longer played a role, and it is difficult to find religion in nineteenth-century presentations of criminal law, such as Paul Johann Anselm Feuerbach's seminal Lehrbuch des gemeinen in Deutschland gültigen peinlichen Rechts (1801). Crimes against religion did not disappear completely, but their importance diminished. Offences which originated in religious morality, such as suicide, where decriminalized. The role of confession in evidence law as a corollary to confession in penitence finally disappeared as free evaluation of evidence (freie Beweiswürdigung, l'intime conviction) gained ground and placed all instruments of proof in the same position. The different kinds of evidence had no intrinsic value as such; instead, their worth was to be evaluated separately in each case.

Nevertheless, the traditional picture of the secularization of criminal law still requires revision. I hope that this article has been able to highlight five points. First, Enlightenment reformers did not invent all the novelties that have traditionally been attached to their names. Religious theories of punishment were already being replaced by those stemming from general and individual deterrence much earlier, in the seventeenth and eighteenth centuries. Although not formally abolished, the 
death penalty and judicial torture were much less used in practically all parts of Europe by the time the Enlightenment launched its attack on these institutions.

Secondly, it is important to emphasize that scholars such as Beccaria, Filangieri and Pagano were not themselves atheists or even anti-religious. Most of the radical, "enlightened" criminal law theorists of the late eighteenth century were, however, anti-church and anti-clergy - against the prevailing prerogatives of the church and its representatives. Here, the criminal law theories of the Enlightenment did not differ from Enlightenment philosophy and political thinking in general. Many of the criminal law reformers were freethinking Christians or deists. Some, like Thomasius and Feuerbach, were Protestants, and it was logical for them to accord the church a minimal role in criminal law, which was the domain of the state.

Thirdly, it is worth noting that Enlightenment criminal law did not completely purge criminal law of Christianity. In some cases, religion could still serve as the background ideology of criminal law. Although Beccaria is not an example of this, Filangieri certainly is. As late as the nineteenth century, some criminal law theorists endorsed Christian betterment as a means of individual deterrence and, therefore, as an important goal of imprisonment. Others accorded Christianity a place in the theory of retribution.

Fourthly, it is important not to forget that although modern criminal law was in many ways a product of the Enlightenment, many of the basic precepts of modern criminal law emerged much earlier in medieval canon law. The medieval canonists were the first to stress the importance of individual responsibility and its different degrees not only for sins but also for crime, and the same canonists came up with most of the justifications and excuses of modern criminal law. These innovations survived the Enlightenment attack on religion.

Fifthly, in most Western countries, active prison reformers were often themselves oriented towards the Christian faith. Alongside labour, religion was, far into the nineteenth century, considered one of primary tools for resocializing and disciplining inmates.

Despite these observations, the fact remains that religion plays little if any role in the criminal law system of the West today. When, then, did the final decisive turn to secularization take place? Thatdiscussion is beyond the confines of this article. However, it seems clear that toward the end of the nineteenth century, positivist criminal law and criminology no longer left any space for religious arguments in the theory of criminal law, at least not in approaches to imprisonment. 
Further reading:

Ahnert, Thomas: Religion and the Origins of the German Enlightenment: Faith and the Reform of Learning in the Thought of Christian Thomasius (University of Rochester Press, Rochester, NY, 2006)

Graber, Jennifer: The Furnace of Affliction: Prisons and Religion in Antebellum America (University of North Carolina Press, Chapel Hill, VA, 2011)

Hostettler, John: Cesare Beccaria: The Genius of 'On Crimes and Punishments' (Waterside Press, Hook, 2011)

Hunter, Ian: The Secularisation of the Confessional State: the Political Thought of Christian Thomasius (Cambridge University Press, Cambridge, 2007)

Ignatieff, Michael: A Just Measure of Pain: The Penitentiary in the Industrial Revolution 1750-1850 (Pantheon Books, New York, 1978)

Kuttner, Stepjhan: Kanonistische Schuldlehre von Gratian bis auf die Dekretalen Gregors IX systematisch auf Grund der handschriftlichen Quellen dargestellt (Biblioteca Apostolica Vaticana, Città del Vaticano [Vatican City?], 1935)

Langbein, John: Torture and the Law of Proof: Europe and England in the Ancien Régime (The University of Chicago Press, Chicago, 1976)

Schmoeckel, Mathias, Humantität und Staatsräson: Die Abschaffung der Folter in Europa und die Entwicklung des gemainen Straf- und Beweisrechts seit dem hohen Mittelalter, 93-186 (Böhlau, Cologne, 2000)

Whitman, James Q.: 'The Transition to Modernity' in Dubber, Markus D. and Hörnle, Tatjana (eds.): The Oxford Handbook of Criminal Law, 84-110 (Oxford University Press, Oxford, 2013) 